Original Article

\title{
Sickle Cell Anemia; 3 Years Clinical Experience in Bisha, Saudi Arabia (2010-2013)
}

\section{Yahya Aziz', Warda Musharraf', Syed Ibrar Hussain Shah ${ }^{2}$ and Muhammad Tayeb²}

1. Department of Medicine, Hamdard University Hospital, Karachi, Pakistan.

2. Department of Medicine, King Abdullah Hospital, Bisha, KSA.

Corresponding Author: drmy.21@gmail.com

\begin{abstract}
Objective Three-year clinical experience of patients diagnosed with Sickle cell disease in Bisha, South Western region of Saudi Arabia is analyzed. Methodology A retrospective analysis was done on data recruited from 2011 to 2013 of all the patients presented with sickle cell anemia. The demographic data, clinical presentation, course of disease, complications and chronic conditions were collected. The descriptive percentage of data with years of presentation and its incidence rate per 100 person-years were also taken with the cause mortality. Results Total 386 patients were analyzed, among them $45.2 \%$ were females and $54.8 \%$ were males. According to our study, the sickle cell crises included as acute chest syndrome (26\%), pulmonary hypertension (21\%), Splenomegaly (7\%), septicemia (11\%), acute Vaso-occlusive crisis (10\%), and other sickle cell crisis $(2-10 \%)$ of patients. It was also found that about $48 \%$ of patients suffered from 1 or more irreversible organ damage. The survival rate of male and female are not significant, however total 82 patients died of sickle cell anemia. Conclusions Sickle cell disease represents high mortality in Saudi Arabia, comprising distinctive diseases characteristic in different regions. The qualitative and quantitative study of genetic and environmental factors in relation to disease complications need to be done.
\end{abstract}

Keywords

Sickle Cell Anemia, Hemoglobinopathy, Sickle Cell Crisis, Acute Chest Syndrome

Introduction

Sickle Cell Anemia is a single gene hemoglobinopathy, which represent the abnormal production of hemoglobin S. This autosomal recessive disorder has a high occurrence among all other hemoglobinopathies ${ }^{1}$. The genetic carriers of Sickle Cell Anemia comprise about 3\% of the total world's population, as mentioned by the World Health Organization ${ }^{2}$. The Sickle Cell Anemia affected about 100, 000 people of the United States, among them 2 million are carrier ${ }^{3}$ however, embarked decline in the mortality ${ }^{4}$ and the mean age of death in male is 53 years and in female about 58 years ${ }^{5}$. In Pakistan, $0.5-1 \%$ of populationis carriers of Hemoglobin $\mathrm{S}^{6}$, whereas about $5.1 \%$ of prevalence found in Karachi $^{7}$. The prevalence of Sickle cell disease is $1.4 \%$ in some regions of Saudi Arabia $^{8}$. The high regional prevalence of Sickle Anemia led to the commencement of national and regional sickle cell screening programs in newborn and married couples ${ }^{9}$.

In this study, the findings from three years' clinical experience of patients with sickle cell disease in Bisha, Saudi Arabia are evaluated. Moreover, the overview of the mortality and morbidity is also analysed along with the reversible and irreversible life threatening complications. 


\section{Methodology}

Three-year retrospective observational study was conducted in the Bisha, Al-Asir SouthWestern province of Saudi Arabia. The data was collected from 2011 to 2013 of all the diagnosed patients with sickle cell disease and presented in medical institute of Bisha. The demographic data, clinical presentation, course of disease, complications and chronic conditions were collected. Among all the hemoglobinopathies, 386 patients were recruited for analysis with sickle cell anemia (Hb SS). The data inquired about age, sex, disease onset, family history, comorbidity, and clinical history. $\mathrm{Hb}$ Electrophoresis is used to diagnose the patients with Sickle Cell Diseases.The distribution percentages of patient by age, sex and course of disease, and its incidence rate per 100 person-years were taken according to the number of participants with the acute or chronic events and the age and gender. The data analysis was done using the SPSS 21.0, whereas the tables and graphs are designed in Microsoft Excel 2010.

Ethical Consideration The study was approved by the ethical committee of respective institutions. Written consent was taken from all the recipients. The personnel of the recipients were made hidden to secure confidentiality.

\section{Results}

The total population size of our study was 386 sickle cell disease patients, among them $45.2 \%$ were females and $54.8 \%$ were males, whereas, $6.20 \%$ were of less than 11 years of age, $16.16 \%$ were less than 15 years of age, $50.30 \%$ were about15-20 years, and $27.24 \%$ were between 20-24 years. However, $39 \%$ of the patients inducted into the study during 2011, and $26 \%$, and $17 \%$ entered during the 2012 to 2013, respectively (Table 1). It is also noted that the rate of hospitalization is increased with the presentation of acute sickle crisis during the year 2012 and 2013, in relation with the age group, having $77 \%$ hospitalization rate.

According to our analysis, the hospitalization rate is associated with the associated primary complications such as $26 \%$ of acute chest syndrome, $21 \%$ of pulmonary hypertension, $11 \%$ Bacterial infection and $7 \%$ of splenomegaly with acute splenic sequestrations. However, hypersplenism was noted more in young children of age group less than 11 years of age. Acute Vaso-occlusive crisis was noted in $10 \%$ of cases. Other sickle cell crisis like Aplastic crisis, Bone infarction, Neurologic disorder, Dactylitis and Priapism were reported in $2-10 \%$ of patients (Table 2).

The irreversible organ damage in sickle cell anemia was presented in patient having $24.21 \%$ of gall bladder disease, $22.19 \%$ of avascular necrosis, $16.22 \%$ of chronic lung diseases, $0.9 \%$ of leg ulcers, $6.30 \%$ of priapism, $7.6 \%$ of renal failure, $10.59 \%$ cerebrovascular diseases, and $5.7 \%$ of retinopathy. Moreover, it was also found that about $48 \%$ of patients suffered from 1 or more of these diseases due to sickle cell anemia. Chronic conditions which are not related to sickle cell disease are found to occur in $3 \%$ of patients (Table 3 ).

The occurrence of chronic conditions showed the highest incident of chronic lung disease about 77\%, acute vaso-occlusive crisis 53\%, renal failure about $75 \%$, osteonecrosis about $74 \%$, retinopathy about $74 \%$, priapism about $69 \%$, gall bladder diseases about $62 \%$ and CVA about $51 \%$. The cause mortality is shown in graph 1. 
Table 1: Distribution of Sickle cell anaemia patients and person-years of observation with age group and number of years in percentage $(n=386)$

\begin{tabular}{|c|c|c|}
\hline Age group & \multicolumn{2}{|c|}{ Occurrence of Sickle Cell Anemia } \\
\hline & Patients Seen & Person-years \\
\hline less than 11 years & $6.20 \%$ & $18.33 \%$ \\
\hline 11-15 years & $16.16 \%$ & $52.01 \%$ \\
\hline 15-20 years & $50.30 \%$ & $35.42 \%$ \\
\hline 20-24 years & $27.24 \%$ & $10.00 \%$ \\
\hline
\end{tabular}

Out of 386 patients of sickle cell anemia gathered, 82 patients died. The survival rate of male and female patients was significantly equal $(p=<0.001)$. The age of survival for male patients was found between 23 - 26 years of age, whereas for female between 22- 24 years of age. The higher incidence of deaths (72\%) found in patients aged between 20-22 years.

\begin{tabular}{|c|c|}
\hline \multicolumn{2}{|c|}{ Table 2: Sickle Cell Crisis $(\mathbf{n = 3 8 6})$} \\
\hline Acute Sickle cell crisis & \% of patients with crisis \\
\hline Hospitalization & 77 \\
Sickle related & 74 \\
Painful Sickle crisis & 69 \\
Associated Sickle crisis & 49 \\
\hline Acute Chest syndrome & 26 \\
Pulmonary Hypertension & 21 \\
\hline Splenomegaly & 7 \\
Acute Vaso-occlusive crisis & 10 \\
\hline Bone Infarction & 3 \\
\hline Aplastic Crisis & 2 \\
\hline Trauma & 5 \\
\hline Septicemia/ Meningitis & 11 \\
\hline Neurological Disorders & 10 \\
\hline Dactylitis at age <4 year & 2 \\
Priapism (male $>17$ year) & 3 \\
\hline
\end{tabular}

\begin{tabular}{|c|c|c|c|}
\hline \multicolumn{4}{|c|}{ Table 3: Organ Damage in Sickle Cell Anaemia } \\
\hline Conditions & & $\begin{array}{c}\text { \% of Patients } \\
\text { With Damage }\end{array}$ & $\begin{array}{c}\text { Age at Diagnosis/Death } \\
\text { (year)Mean }\end{array}$ \\
\hline Organ & Gall bladder disease & $24.21 \%$ & 21 \\
Damage & Avascular necrosis & $22.19 \%$ & 20 \\
& Chronic lung disease & $16.22 \%$ & 22 \\
& Leg ulcer & $0.9 \%$ & 18 \\
& Priapism (male >17 year) & $6.30 \%$ & 22 \\
& Renal failure & $7.6 \%$ & 21 \\
& Cerebrovascular accident & $10.59 \%$ & 16 \\
\hline
\end{tabular}


Figure 1: Shows causes of mortality

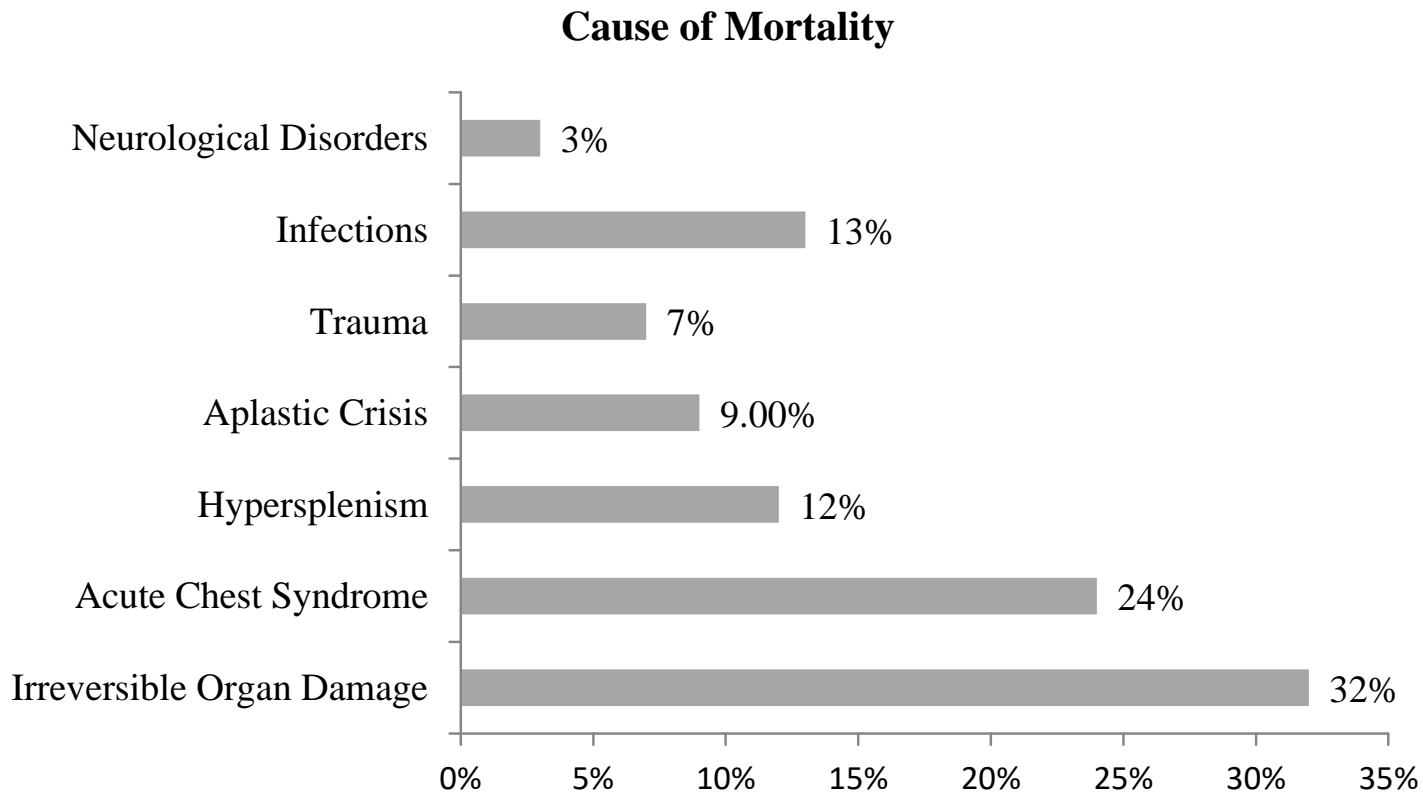

\section{Discussion}

Sickle cell anemia is coupled with high mortality due to acute sickle crisis and irreversible organ damage. However, since the implementation of the Saudi Premarital Screening and Genetic Counseling (PMS\&GC) in 2004, the mortality is significantly reduced ${ }^{9}$. In South Western Region of Saudi Arabia, the prevalence of SCD is reported as about $28.5 \%$. The present retrospective three-year observational study was done to analyze the mortality and morbidity of Sickle Cell Disease in Bisha, Saudi Arabia. Among the 386 recruitment of SCD as outpatient or admission to hospital, 82 patients died. There was no significant difference in mortality of male and female, having the mean age of 23 for female and 24 for males. The mortality ratio is significantly high as compared to other regions of Saudi Arabia and other part of world ${ }^{10}$. Whereas, the mean age is of survival is low as compare to United States and Africa, where the mean age reaches to 30 years or older ${ }^{11,12}$. The main culprit of death in the Bisha region was acute sickle crisis with or without irreversible organ damage.

Acute chest syndrome is responsible for high mortality and reported as the major complication of death. It is noted that the frequency of hospitalization with acute chest syndrome is higher as compared to Eastern region of Saudi $\mathrm{Arab}^{13}$. Moreover, the increase mortality due to acute chest syndrome is higher in younger age groups ${ }^{14}$, as found in our study. The prior complain of asthma was also noted in young children that depicts the finding of previous studies ${ }^{15}$. Moreover, the increase leukocyte counts found in our patients represented the proinflammatory cause of acute chest syndrome as seen in most of the patients ${ }^{16}$.

Pulmonary hypertension is another common consequence of sickle cell anemia as per study. The main cause of death in SCD is pulmonary hypertension, comprising $11.2 \%$ prevalence in United States and United 
Kingdom ${ }^{17}$. This study is coherent with the Brazilian cohort which shows $10 \%$ pulmonary hypertension prevalence ${ }^{18}$. A study was done in Tertiary care hospital in Saudi Arabia, reported to have $38 \%$ prevalence ofpulmonary hypertension in Sickle Cell disease, moreover showed high morbidity and mortality index in hemoglobinopathies ${ }^{19}$. Furthermore, in Al Hassa region pulmonary arterial hypertension was evaluated by Doppler echocardiography, given $37.1 \%$ incidence $^{20}$.

There was comparatively low incidence of leg ulcers and priapism in Bisha region similar to prior findings ${ }^{21}$. Priapism is under reporting complication, rather knowing that it might worsen the disease ${ }^{22}$. However, the low incidence of leg ulcers represented the distinction of genotype and environmental factors $^{23}$.

\section{Conclusion}

The complications and severity of Sickle cell disease vary with the genotype and environmental factors. Our study is limited by not evaluating genotype of Sickle cell disease and limited age group majority was greater than 15 years old. This qualitative and quantitative measure would embark the significance of large study comparing both genotype and environmental factors with disease presentation.

\section{Conflict of interest}

None

\section{Acknowledgement}

None

\section{References}

1. Steinberg, M. H., Chui, D. H., Dover, G. J., Sebastiani, P., \& Alsultan, A. (2014). Fetal hemoglobin in sickle cell anemia: a glass half full? Blood,123(4), 481-
485. Accessed January 17, 2017. https://doi.org/10.1182/blood-

2013-09-528067.

2. WHO, 2011. Fact sheet: sickle cell disease and other hemoglobin disorders. Retrieved from http://www.who.int/mediacentre/factshee ts/fs308/en

3. Okam, M. M., Shaykevich, S., Ebert, B. L., Zaslavsky, A. M., \&Ayanian, J. Z. (2014). National trends in hospitalizations for sickle cell disease in the United States following the FDA approval of hydroxyurea, 19982008. Medical care,52(7), 612-618. Gibbons, C., Geoghegan, R., Conroy, H., Lippacott, S., O'Brien, D., Lynam, P., ... \& McMahon, C. (2015). Sickle cell disease: time for a targeted neonatal screening programme.Irish medical journal.

4. Piel, F. B., Hay, S. I., Gupta, S., Weatherall, D. J., \& Williams, T. N. (2013). Global burden of sickle cell anaemia in children under five, 20102050: modelling based on demographics, excess mortality, and interventions. PLoS Med, 10(7), e1001484. doi: 10.1371/journal.pmed.1001484.

5. Hashmi, N. K., Moiz, B., Nusrat, M., \& Hashmi, M. R. (2008). Chromatographic analysis of $\mathrm{Hb} \mathrm{S}$ for the diagnosis of various sickle cell disorders in Pakistan. Annals of hematology, 87(8), 639-645.

6. Ahmed, S., Saleem, M., Modell, B., \&Petrou, M. (2002). Screening extended families for genetic hemoglobin disorders in Pakistan. New England journal of medicine, 347(15), 1162-1168.

7. Jastaniah, W. (2011). Epidemiology of sickle cell disease in Saudi Arabia. Annals of Saudi medicine, 31(3), 289. 
8. Zaini, R. G. (2016). Sickle-cell anemia and Consanguinity among the Saudi Arabian population. Archives of Medicine.

9. Lanzkron, S., Carroll, C. P., \& Haywood Jr, C. (2013). Mortality Rates and Age at Death from Sickle Cell Disease: US, 1979-2005. Public health reports, 110116.

10. Hamideh, D., \& Alvarez, O. (2013). Sickle cell disease related mortality in the United States (1999-2009). Pediatric blood \& cancer, 60(9), 1482-1486.

11. Makani, J., Williams, T. N., \& Marsh, K. (2013). Sickle cell disease in Africa: burden and research priorities. Annals of tropical medicine and parasitology.

12. Alsultan, A., Alabdulaali, M. K., Griffin, P. J., AlSuliman, A. M., Ghabbour, H. A., Sebastiani, P., ... \& Steinberg, M. H. (2014). Sickle cell disease in Saudi Arabia: the phenotype in adults with the Arab-Indian haplotype is not benign. British journal of haematology, 164(4), 597-604.

13. Anea, C. B., Lyon, M., Lee, I. A., Gonzales, J. N., Adeyemi, A., Falls, G., ... \&Brittain, J. E. (2016). Pulmonary platelet thrombi and vascular pathology in acute chest syndrome in patients with sickle cell disease. American journal of hematology, 91(2), 173-178. doi: 10.1002/ajh.24224.

14. DeBaun, M. R., \& Strunk, R. C. (2016). The intersection between asthma and acute chest syndrome in children with sickle-cell anaemia. The Lancet, 387(10037), 2545-2553.

15. Hebbel, R. P. (2014). Ischemiareperfusion injury in sickle cell anemia: relationship to acute chest syndrome, endothelial dysfunction, arterial vasculopathy, and inflammatory pain. Hematology/oncology clinics of North America, 28(2), 181-198.

16. Gladwin, M. T., Barst, R. J., Gibbs, J. S. R., Hildesheim, M., Sachdev, V., Nouraie, M., ... \&Novelli, E. (2014). Risk factors for death in 632 patients with sickle cell disease in the United States and United Kingdom. PloS one, 9(7), e99489.

17. Fonseca, G. H. H., Souza, R., Salemi, V. M. C., Jardim, C. V. P., \&Gualandro, S. F. M. (2012). Pulmonary hypertension diagnosed by right heart catheterisation in sickle cell disease. European Respiratory Journal, 39(1), 112118.

18. Saleemi, S. (2014). Saudi Guidelines on the Diagnosis and Treatment of Pulmonary Hypertension: Pulmonary hypertension associated with hemolytic anemia. Annals of thoracic medicine, 9(Suppl 1), S67.

19. Al-Khoufi, E. A. S. (2013). Prevalence of pulmonary arterial hypertension among sickle cell disease patients in $\mathrm{Al}$ Hassa. Global journal of health science, 5(5), 174. Saraf, S. L., Molokie, R. E., Nouraie, M., Sable, C. A., Luchtman-Jones, L., Ensing, G. J., ... \& Gladwin, M. T. (2014). Differences in the clinical and genotypic presentation of sickle cell disease around the world. Paediatric respiratory reviews, 15(1), 4-12.

20. Al-Salem, A. (2016). Priapism and Sickle Cell Anemia. In Medical and Surgical Complications of Sickle Cell Anemia (pp. 281-291). Springer International Publishing.

21. Delaney, K. M. H., Axelrod, K. C., Buscetta, A., Hassell, K. L., AdamsGraves, P. E., Seamon, C., ... \&Minniti, C. P. (2013). Leg ulcers in sickle cell disease: current patterns and practices. Hemoglobin, 37(4), 325-332. 